\title{
Analysis of Legge and Pound's Versions of Shijing
}

\author{
Hao Zhang \\ North China Electric Power University \\ Baoding, China
}

\begin{abstract}
As the most precious Confucius classic and core of Chinese traditional culture, Shijing has dominated Chinese ideology for thousands years with its profound historical and cultural connotation and denotation. This thesis intends to analyze James Legge and Ezra Pound's versions of Shijing from linguistic and cultural perspectives. In this thesis, Eugene Nida's principles of correspondence are adopted as theoretical support. The formal equivalence and dynamic equivalence theories are applied for detailed comparisons and analyses.
\end{abstract}

Keywords—principles of correspondence; Shijing translation

\section{INTRODUCTION}

Shiijing is so popular in worldwide scope and its translation work attracted numerous translators from home and abroad endeavoring for almost 400 years. So far, the specialized studies for Shijing translation from the translatology angle are terribly in short supply in translation studies field. A large amount of complementary and even expansible works need to be done. Without this kind of fundamental studies, the comprehensive and profound studies for Shijing translation are certain to encounter obstacles.

Formal equivalence focuses attention on the message itself, in both form and content. Viewing from this formal orientation, one is concerned that the message in the receptor language should match as closely as possible the different elements in the source language. In dynamic orientation translation, the translation standard is that the relationship between receptor and message should be substantial the same as that which existed between the original receptors and the message. At the same time Nida emphasis that a translation of dynamic equivalence aims at complete naturalness of expression, and tries to relate the receptor to modes of behavior relevant within the context of his own culture; it does not insist that he understands the cultural patterns of the source-language context in order to comprehend the message.( Nida, 2004:158)

Considering Pound's cultural background, it is clear that Pound put content as the dominant consideration. This is one factor governing his translation oriented toward dynamic equivalence. Owing to the cultural background, religious and philosophical viewpoints, Legge treated Shijing the way he treated Bible, that is strictly, thoroughly to obey the interpretation of the authoritative texts, even for the spot of doubts. It is clear that Legge put form as the dominant consideration. This is one factor governing his translation

The research was supported by "the Fundamental Research Funds for the Central Universities of China"( Grant No.13MS124). oriented toward formal equivalence.

Pound translated the old for the present and expressed himself by translating Confucianism. In Pound's translation, the focus of attention is directed toward the receptor response but not so much toward the source message. Viewing from Pound's translating purposes, his translation of Shijing produced a dynamic rather than a formal equivalence. The fundamental reason why Legge rendered Shijing into English was largely related to his strong sense of duty as a missionary in a heathen world. Legge believed that missionaries should learn to understand the Chinese language and culture and the study of Confucian would help to better promote the evangelization in ancient China. In Legge's translation the focus of attention is directed toward the source message but not so much toward the receptor response. Viewing from Legge's translating purposes, his translation of Shijing produced a formal rather than a dynamic equivalence.

By comparing Pound's version with Legge's from the viewpoints of the cultural background, the purposes of the translators and the type of audience, the writer came to a conclusion that good translation is not determined by whether it is formal or dynamic equivalence so long as to meet the needs of different types of audiences.

\section{LEGGE' S VERSIONS OF SHIJING}

Legge focuses attention on the original poems of Shijing, in both form and content. This is typical translation oriented toward formal equivalence. In such a translation one is concerned sentence to sentence, and concept to concept. Viewed from this formal orientation, one is concerned that the message in the receptor language should match as closely as possible the different elements in the source language. This means, for example, that the message in the receptor culture is constantly compared with the message in the source culture to determine standards of accuracy and correctness. The type of translation which most completely typifies this structural equivalence might be called a "gloss translation," in which the translator attempts to reproduce as literally and meaningfully as possible the form and content of the original" . (Nida, 2004:8) The most outstanding performances in Legge' $s$ versions of Shijing are that he rewrote and gave statements to the preliminary remarks and the contents translation and moreover demonstrate apparent Ruist character by highlighting the political and ethical significance. A gloss translation of this type is designed to permit the reader to 
identify himself as fully as possible with a person in the source-language context, and to understand as much as he can of the customs, manner of thought and means of expression.

Viewing from the academic history of Shijing, it is not the literary poetry initially in the sense of modern poetics. The ultimate goals of Confucianism in previous ages of reading, studying and interpreting Shijing is to use it without exception serving for the feudal rules. All these were reflected in Legge's version which considered culture and ideology as value orientation and was translated up to the highest principle of "faithfulness".

The feudal code of moral and ethics in Legge's version of Shijing were profoundly manifested in the translations of love and marriage poems.

\section{POUND' S VERSION OF SHIJING}

"One thing seems clear: to translate a poem whole is to compose another poem. A whole translation will be faithful to the matter, and it will 'approximate the form' of the original; and it will have a life of its own, which is the voice of the translator.'(Jackson Mathews, 1959:67) This definition of proper translating is a vivid illustration for Pound's version of Shijing. In poetry translation, the tension between form and content and the conflict between formal and dynamic equivalences are always acutely present. However, it seems to be increasingly recognized that adherence to the letter may indeed kill the spirit. Ezra Pound's version of Shijing takes up a significant position in Shijing translation history and has arisen some controversies over the west. The one who was against him criticized his disloyalty to the source text and the one who was with him thought that although Pound's version differ a lot with the source in semantics, it is quite similar in spirit. William A. Cooper deals with this problem rather realistically in his article on "Translating Goethe's Poems", in which he says: "If the language of the original employs word formations that give rise to insurmountable difficulties of direct translation, and figures of speech wholly foreign, and hence incomprehensible in the other tongue, it is better to cling to the spirit of the poem and clothe it in language and figures entirely free from awkwardness of speech and obscurity of picture.

The resolution of the conflict between literalness of form and equivalence of response seems increasingly to favor the latter, especially in the translating of poetic materials. Ezra Pound states the case for translations making sense by declaring for "more sense and less syntax." In addition to making sense, translations must also convey the "sprit and manner" of the original. This determined the dynamic equivalence orientation of Ezra Pound's version of Shijing. What's more, people confirmed Pound's version from the translation literature standpoint. Pound's version of Shijing had excited some scholar's attentions in China who mainly discussed Pound's translation peculiarity with an eye to some individual cases, such as musicality, misinterpretation and recomposition, etc. How to regard Pound's version, however, is not just a question about faithful or not. Accurately speaking, in the process of rendering Shijing into English, Pound did not pursue being faithful to the source poem in semantic content.
His translation did not follow the traditional way, but recomposed the source poem by applying imagism technique, so to a large extent, it is a kind of creative writing. In general, Pound's version of Shijing differs widely with the source poem in both form and content and this is not Pound's fault nor by accident, but lies in the embodiment of his translation purposes, strategies and objectives. The conformance of a translation to the receptor language and culture as a whole is an essential ingredient in any stylistically acceptable translation. Such an adjustment to the receptor language and culture must result in a translation that bears no obvious trace of foreign origin. (Nida, 2004:158) In fact, Pound carries out imagism in his translation works. He stated that do not try to present the integral meaning of a piece of work but to translate the exact work, cluster of fused ideas or even broken image. And the exact work, according to Richard Aldington, another of the first Imagists, must bring the effect of the object before the reader as it had presented itself to the poet's mind at the time of writing. An imagist poem enables the reader to see the physical thing rather than put him through an abstract process. This resulted that in Pound's version of Shijing the focus of attention is directed, not so much toward the source message, as toward the receptor response. This determined the dynamic equivalence orientation of Ezra Pound's version of Shijing.

Something like an Imagist manifesto came out in 1912 in which Pound and Flint laid down three Imagist poetic principles: (1) Direct treatment of the "thing," whether subjective or objective; (2) To use absolutely no word that does not contribute to the presentation; and (3) As regarding rhythm, to compose in the sequence of the musical phrase, not in the sequence of a metronome. The first principle, with its emphasis on direct treatment, indicates a desire to make the expression resemble the "object" as closely as art can make it. By "direct," Pound means no fuss, frill, or ornament. The second stresses economy of expression, a reaction to the nineteenth-century tendency of philosophical "padding" of extra-poetic matter, or "emotional slither." To Ezra Pound any unnecessary word represents a loss of precision and a moral and artistic defection. The third concerns a breaking away from conventional prosody and the use of free verse, and the interrelationship between music and verse. Pound did not mean to sponsor "free verse" as the only verse form to use: he advocated freedom in verse. "Free Verse" means form, not formlessness.

Pound's translation had realistic social and political meaning. Imagism principle made Pound's translation had art charm of Imagism poem and important meaning for further develop and perfect Imagism poetics.

\section{CONCLUSION}

This thesis applies the principles of correspondence to the study of Shijing translation by comparing Legge's and Pound's versions of Shijing from the aspects of formal equivalence and dynamic equivalence to prove the possibility of poetry translation and provide theoretical guidance function to poetry translation.

Viewing from the comparison between Legge and Pound's versions of Shijing, the two extreme translation grades 
appeared basing on the same source text. The factors that lead to this kind of distinction may be summarized as follows, namely the subjective reasons of the translators and the objective reasons of linguistic and cultural history. The interaction between the two factors may produce endless specific factors that influence translation process. Just these specific factors decide the many different types of translations among which the psychological factors and the translator's purposes are the most important ones in dictating the formalequivalence oriented translation of Legge's versions and the dynamic equivalence oriented translation of Pound's version of Shijing. We can say that Legge is thoughtful and pursuing accurateness while Pound is to translate the old for the present.

\section{REFERENCES}

[1] Nida, E.A.Toward a Science of Translating. [M]. Shanghai Foreign Language Education Press, 2004.

[2] James Legge. The Book of Poetry: Chinese Text with English Translation. [M]. Shanghai: The Commercial Press, LTD, 1936.

[3] Pound, Ezra. Poems and Translation.[M].Library of America, 2003. 